\title{
PENINGKATAN HASIL BELAJAR SISWA SEKOLAH DASAR MELALUI MODEL STUDENT FACILITATOR AND EXPLAINING BERBANTUAN MEDIA ROTAR
}

\section{Munia Ningsih, Sumarwiyah, dan Deka Setiawan}

Universitas Muria Kudus

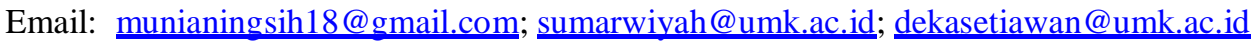

\section{Info Artikel}

Sejarah Artikel:

Diserahkan 18 Juli 2020

Direvisi 10 Agustus 2020

Disetujui 03 November 2020

Keywords:

leaning outcomes,

student facilitator and

explaining,

rotar media

\section{Abstract}

The reseach aims to describe the improvement of the Students outcomes at the fourth grade of SDN 1 Payaman trough the Student Facilitator and Explaining science learning models and rotar media in the seven themes indahnya keragaman di negeriku.

The research design is a classroom action research that is conducted in two cycles by the number of subjects 29 students. The data collection of this study utilized the interview, observation, test, and documentation. The data analysis is qualitative and quatitative data. The result of the research showed that Students Facilitator and Explaining this science learning model and rotar media improve the students knowledge. In the cycle one the knowledge domains of IPS in classical terms the percentage got $62.06 \%$ and the mean was 72.24 , while in the domain of indonesia the percentage got $65.51 \%$ and the mean was 74.82. in the cycle two for the domain of IPS was gained with a percentage of $89,65 \%$ with the mean 83.62. while on the domain of Indonesia got a percentage of $93.10 \%$ with the mean 86.03 .

\begin{abstract}
Abstrak
Penelitian ini bertujuan untuk mendiskripsikan peningkatan hasil belajar siswa kelas IV SDN 1 Payaman melalui model Student Facilitator and Explaining berbantuan media rotar pada tema 7 indahnya keragaman di negeriku.

Jenis penelitian yang digunakan adalah Penelitian Tindakan Kelas yang dilakukan dalam dua siklus dengan subjek penelitian berjumlah 29 siswa. Teknik pengumpulan data yang digunakan adalah wawancara, observasi, tes dan dokumentasi. Data yang terkumpul dianalisis dengan analisis data kualitatif dan kuantitatif.

Hasil Penelitian menunjukkan bahwa model student facilitator and explainig berbantuan media rotar dapat meningkatkan hasil belajar siswa pada ranah pengetahuan. Pada siklus I ranah pengetahuan siswa muatan IPS secara klasikal memperoleh persentase $62.06 \%$ dengan rata-rata 72.24, sedangkan pada muatan Bahasa Idonesia memperoleh pesentase $65.51 \%$ dengan rata-rata 74.82. Pada siklus II mengalami peningkatan dengan persentase sebesar $89.65 \%$ dengan rata-rata 83.62 pada muatan IPS, sedangkan pada muatan Bahasa Indonesia memperoleh persentase $93.10 \%$ dengan rata-rata 86.03 .
\end{abstract}




\section{PENDAHULUAN}

Pendidikan merupakan salah satu faktor penting untuk mempersiapkan kesuksesan pada zaman globalisasi saat ini sesuai dengan perkembangan ilmu teknologi dan pengetahuan. Hal tersebut perlu diimbangi adanya upaya untuk peningkatan kualitas sumber daya manusia yaitu salah satunya meningkatkan mutu pendidikan. Nurkholis (2013) menjelaskan pendidikan merupakan aktifitas yang mempunyai maksud dan tujuan untuk mengembangkan potensi yang dimiliki manusia. Pendidikan tentunya memuat kurikulum yang menjadi pedoman dalam malaksanakan pembelajaran. Hanafy (2014) menjelaskan bahwa pembelajaran merupakan suatu proses belajar untuk memperoleh pengetahuan, penguasaan materi, serta untuk membentuk sikap dan kepercayaan yang lebih baik. Kurikulum yang diterapkan yaitu kurikulum 2013. Dimana dalam kurikulum 2013 menekankan pada pembelajaran yang dilakukan secara tematik. Utari et al (2016) menyatakan pembelajaran tematik merupakan keterkaitan antar satu bidang mata pelajaran dengan bidang lainnya yang dikemas menjadi satu dalam sebuah tema. Senada dengan pendapat Ardianti (2015) bahwa pembelajaran tematik sebagai pembelajaran dengan memadukan beberapa materi atau bahan kajian dalam satu tema pembelajaran. Tematik mengintegrasikan kedalam beberapa mata pelajaran kedalam tema-tema dan subtema sehingga diharapkan dapat berjalan secara efektif dan efisien.

Berdasarkan hasil observasi di SDN 1 Payaman khususnya dikelas IV diketahui babhwa perolehan hasil belajar siswa pada muatan IPS dan Bahasa Indonesia cenderung rendah. Data hasil ulangan harian pada muatan Bahasa Indonesia dari jumlah 29 siswa yang dapat melampaui KKM hanya 12 siswa dan jumlah siswa belum tuntas 17 siswa. Pada muatan IPS siswa yang tuntas 10 siswa dan yang belum tuntas 19 siswa dengan KKM yang ditetapkan adalah 70. Data tersebut menunjukkan pembelajaran yang dilaksanakan belum berhasil dan perlu adanya perbaikan.

Berdasarkan wawancara dan observasi dengan guru dan siswa IV di SD 1 Payaman, diketahui bahwa siswa merasa kesulitan untuk memahami apa yang dijelaskan dengan hanya mendengarkan guru ceramah terutama pada muatan IPS dan Bahasa Indonesia. Muatan IPS dan Bahasa indonesia yang terlalu banyak materi, dan terlalu banyak bacaan yang dianggap siswa membosankan. Permasalahan lain yaitu pembelajaran yang masih berpusat pada guru sehingga akan memberikan dampak pada keterbatasan siswa dalam mengembangkan ide atau potensi yang dimiliki siswa.

Berdasarkan kondisi yang terjadi diatas yaitu hasil belajar siswa pada muatan IPS dan Bahasa Indonesia masih rendah. Untuk mengatasi hal tersebut perlu adanya suatu strategi atau inovasi baru agar pembelajaran lebih menarik, menyenangkan dan tentunya tidak membosankan sehingga pembelajaran yang dilakukan lebih maksimal dan dapat meningkatkan hasil belajar siswa. Salah satu strategi yang dapat diterapkan guru untuk membuat pembelajaran lebih menarik dan berkesan bagi siswa yaitu dengan menerapkan model dan media pembelajaran yang sesuai dan media yang menarik perhatian siswa. Dengan model dan media yang menarik tentunya akan membuat siswa lebih semangat dan termotivasi dalam proses pembelajaran. Maesaroh (2013) menjelaskan bahwa dengan metode pembelajaran yang menarik dapat menjadi jembatan tercapainya kompetensi yang diharapkan. Pencapaian kompetensi tersebut akan meningkatkan minat dan perhatian siswa serta meningkatnya hasil belajar.

Berdasarkan kondisi di lapangan maka peneliti berusaha menerapkan model pembelajaran untuk mempermudah guru dalam melaksanakan pembelajaran. Trianto (2014) menjelaskan model Pembelajaran adalah sebuah perencanaan atau pola yang dijadikan sebagai panduan dalam melaksanakan pembelajaran yang dilakukan di kelas ataupun pembelajaran yang diklakukan diluar kelas. Sedangkaan Sundari (2015) menyatakan model pembelajaran merupakan strategi yang dirancang berdasarkan landasan teori pada penelitian tertentu berdasarkan latar belakang, posedur pembelajaran, sistem pendukung dan evaluasi pembelajaran yang ditujukan untuk pengajar dan siswa dalam mencapai tujuan pembelajaran.

Model Student Facilitator and Explaining merupakan salah satu jenis model pembelajaran kooperatif. Shoimin (2014) menyatakan bahwa model student faciitator and explaining merupakan salah satu model pembelajaran kooperatif yang menekankan pada struktur khusus untuk mempengaruhi interaksi siswa dalam penguasaan materi. Model Student Facilitator and Explaining mengajak siswa memaparkan ide atau pendapatnya mengenai materi yang diberikan guru kepada temannya 


\section{Munia Ningsih, Sumarwiyah, dan Deka Setiawan \\ PENINGKATAN HASIL BELAJAR SISWA SEKOLAH DASAR MELALUI MODEL STUDENT .... WASIS: Jurnal Ilmiah Pendidikan. Volume 1 Nomor 2, November 2020, hlm. 74-79}

(Rohman, 2017). Guru memberikan kesempatan kepada siswa untuk menjelaskan kepada siswa lainnnya sehingga dapat meningkatkan motivasi belajar siswa serta membuat siswa lebih aktif dan antusias dalam mengikuti pembelajaran. Fitriani (2019) dalam penelitiannya menghasilkan temuan bahwa penerapan model Student Facilitator And Explaining dapat meningkatkan hasil belajar siswa. Selaras dengan pendapat Astuti (2020) menyebutkan bahwa penerapan model Student Facilitator And Explaining dapat meningkatkan aktivitas belajar siswa. Oleh sebab itu model pembelajaran ini sesuai untuk diterapkan guru karena dapat mendorong siswa menguasai beberapa keterampilan salah satunya pada pemahaman materi. Untuk mendukung penggunaan model pembelajaran tersebut peneliti juga menerapkan media pembelajaran.

Media pembelajaran sebagai alat yang digunakan untuk menyampaikan pesan atau informasi dari pengajar kepada peserta belajar (Uno, 2015). ROTAR (Roda putar) sebagai sebuah media berbentuk lingkaran menyerupai roda yang terbagi dalam beberapa sektor pada lingkarannya dan memuat kartu soal (Wahyuni, 2017). Penerapan media rotar dapat membantu siswa dalam meningkatkan hasil belajar. Ayu et al (2019) dalam penelitiannya mengemukanan bahwa penerapan media roda putar dapat meningkatkan hasil belajar siswa. Dalam penelitian ini media rotar dibagi menjadi 10 bagian/sektor yang dalam setiap sektor terdapat gambar-gambar dari keanekaragaman yang ada di indonesia serta terdapat kartu materi yang dapat membantu siswa dalam menjelaskan materi mengenai keragaman yang terdapat di indonesia.

Penggunaan model pembelajaran Student Facilitator and Explaining dengan media rotar akan mendorong siswa akif dan ikut berpartisipasi dalam proses pembelajaraan. Penerapan model pembelajaran ini, tidak hanya guru yang aktif menjelaskan materi tetapi juga siswa ikut berpartisipasi dalam menjelaskan materi, selain beperan aktif dalam proses pembelajaran. Model tersebut juga dapat memberikan pengalaman langsung kepada siswa melalui penggunaan media rotar. Dalam penelitian Kurniadewi (2019) ditemukan bahwa penggunaan media rotar dalam pembelajaran membantu peningkatan aktivitas siswa. melalui media tersebut dapat mempermudah siswa dalam memahami materi dan diharapkan dapat meningkatkan hasil belajar siswa pada ranah pengetahuan.
Tujuan dalam penelitian ini yaitu mendeskripsikan peningkatan hasil belajar siswa dengan menggunakan model Student Facilitator and Explaining berbantuan media rotar pada tema 7 indahnya keragaman di negeriku siswa kelas IV SDN 1 Payaman Kudus.

\section{METODE PENELITIAN}

Penelitian ini merupakan Penelitian Tindakan Kelas (PTK). Penelitian tindakan kelas ini dilaksanakan di kelas IV SDN 1 Payaman dengan subjek penelitian berjumlah 29 siswa. Penelitian ini menggunakan model Kemmis dan Mc. Taggart. Arikunto (2010) menyebutkan terdapat empat tahapan dalam prosedur penelitian yang harus dilalui yaitu perencanaan, pelaksanaan, pengamatan, dan refleksi. Penelitian ini dilakukan dalam dua siklus, pada setiap siklus terbagi atas dua pertemuan.

Teknik pengumpulan data dalam penelitian meliputi teknik wawancara, observasi, dokumentasi dan tes. Wawancara dilakukan untuk memperoleh informasi sebelum dilakukan tindakan, dokumentasi dilakukan untuk mengumpulkan data berupa foto dalam penelitian. Observasi dalam penelitian ini digunakan untuk mengukur kinerja siswa pada aspek keterampilan, pengamatan dilakukan selama proses pembelajaran sedang berlangsung. Tes merupakan instrumen pengumpulan data yang digunakan untuk mengukur pengetahuan siswa pada aspek kognitif. Tes yang digunakan dalam penelitian ini adalah tes tertulis dalam bentuk 10 soal uraian. Data yang terkumpul akan di analisis data yang digunakan adalah analisis data kualitatif dan kuantitatif.

Indikator keberhasilan dalam penelitian ini adalah hasil belajar ranah pengetahuan muatan IPS dan Bahasa Indonesia pada tema 7 Indahnya keragaman di negeriku siswa kelas IV SDN 1 Payaman dengan penerapan model student facilitator and explaining berbantuan media rotar dinyatakan berhasil apabila hasil belajar siswa $\geq 70$ sesui dengan KKM muatan IPS dan Bahasa Indonesia di SDN 1 Payaman.

\section{HASIL DAN PEMBAHASAN}

Penelitian ini dilaksaksanakan dalam dua siklus. Setiap siklus terdiri dari dua pertemuan yang dilaksanakan di SDN Payaman pada kelas IV dengan jumlah 29 siswa. Penelitian ini menerapkan model pembelajaran Student Facilittator and Explaining berbantuan media rotar. Peneliti memfokuskan muatan IPS dan Bahasa Indonesia pada penelitian ini. 
Peningkatan hasil belajar siswa dapat dilihat pada Tabel 1 berikut.

Tabel 1. Peningkatan Hasil Belajar Siswa muatan IPS

\begin{tabular}{cc}
\hline Pelaksanaan & Ketuntasan klasikal siswa \\
\hline Siklus I & $62,06 \%$ \\
Siklus II & $89,65 \%$ \\
\hline
\end{tabular}

Berdasarkan Tabel 1. menunjukkan peningkatan ketuntasan hasil belajar pada ranah pengetahuan muatan IPS dengan presentase perolehan pada siklus I sebesar $62,06 \%$. Pada siklus II meningkat menjadi $89,65 \%$, sehingga peningkatan yang terjadi sebesar $27,59 \%$.

Tabel 2. Peningkatan Hasil Belajar Siswa muatan Bahasa Indonesia

\begin{tabular}{lc}
\hline Pelaksanaan & Ketuntasan klasikal siswa \\
\hline Siklus I & $65,51 \%$ \\
Siklus II & $93,10 \%$ \\
\hline
\end{tabular}

Tabel 2 menunjukkan ketuntasan hasil belajar pada muatan Bahasa Indonesia pada siklus I memperoleh persentase sebesar $65,51 \%$. Pada siklus II meningkat menjadi 93,10\%, sehingga peningkatan yang terjadi sebesar $27,59 \%$

Pelaksanaan pembelajaran siklus I dan II dengan menerapkan model student facilitator and explaining berbantuan media rotar sudah berjalan dengan baik. Namun, terdapat beberapa siswa yang masih belum mencapai indikator keberhasilan yang ditentukan. Hal tersebut dikarenakan siswa masih mencoba untuk beradaptasi dengan model yang baru diterapkan dalam pembelajaran. Elydawati (2019) menyampaikan bahwa siswa memelukan waktu untuk dapat beradaptasi dengan model pembelajaran yang diterapkan oleh guru sebelum mencapai hasil yang maksimal. Oleh sebab itu perlu dilakukan perbaikan dengan cara lebih memotivasi siswa dalam hal belajar sehingga akan menimbulkan kesan yang positif kepada siswa. Sejalan dengan pendapat Suprihatin (2015) menyatakan Proses pembelajaran akan berhasil manakala siswa mempunyai motivasi dalam belajar. dengan motivasi kuat yang dimiliki siswa akan berdampak baik pada kualitas hasil belajar siswa.

Berdasarkan kondisi pada siklus I selanjutnya dilakukan perbaikan pada siklus II dan menunjukkan adanya peningkatan hasil belajar siswa. Peningkatan tersebut ditunjukkan dengan adanya kenaikan persentase ketuntasan klasikal. Selain itu, hasil belajar penelitian tindakan kelas pada ranah pengetahuan ini telah mencapai indikator keberhasilan yang sudah ditetapkan yaitu $70 \%$. Peningkatan hasil belajar siswa dikarenakan penerapan model student facilitator and explaining dan media rotar yang menarik dan menyenangkan sehingga dapat mempermudah siswa dalam menyerap materi pelajaran. Azizah dan Fitrianawati (2020) berpendapat bahwa penggunaan media yang sesuai dapat membantu siswa dalam memahami materi. Penggunaan media dan model pembelajaran dapat menjadikan pembelajaran menarik dan menyenangkan yang berdampak pada peningkatan hasil belajar. Sejalan dengan pendapat Ardianti (2019) bahwa pembelajaran yang dikemas secara menarik dan menyenangkan dapat meningkatkan motivasi belajar siswa yang akan berdampak pada peningkatan hasil belajar. Supriyono (2018) juga menjelaskan bahwa alat bantu mengajar media pembelajaran sangat memudahkan siswa dalam hal belajar karena media dapat membuat hal-hal yang bersiat abstrak menjadi lebih konkrit (nyata).

Penerapan model student facilitator and explaining dalam penelitian ini terbukti berhasil dalam meningkatkan hasil belajar siswa dari siklus I ke siklus II. Hal ini didukung dengan hasil penelitian Pangasean (2016) bahwa penerapan model student facilitator and explaining dapat meningkatkan hasil belajar siswa dalam kategori baik. Sentosa (2015) menyatakan bahwa penerapan model student facilitator and explaining dapat meningkatkan aktivitas siswa yang akan berdampak pada peningkatan hasil belajarnya. Selaras dengan pendapat Elydawati (2019) bahwa penerapan student facilitator and explaining dapat meningkatkan rata-rata klasikal hasil belajar siswa.

\section{SIMPULAN}

Berdasarkan hasil penelitian dan pembahasan penelitian tindakan kelas yang telah dilaksanakan pada siswa kelas IV dengan menggunakan model Student Facilitator and Explaining berbantuan media rotar dapat meningkatkan hasil belajar siswa pada ranah pengetahuan siswa kelas IV SDN 1 Payaman pada tema 7 Indahnya Keragaman di Negeriku.

Hasil belajar siswa pada ranah pengetahuan mengalami peningkatan. Pada setiap siklusnya, siklus I ranah pengetahuan 
muatan IPS secara klasikal memperoleh persentase $62,06 \%$ meningkat pada siklus II menjadi $89,65 \%$. Muatan Bahasa Indonesia siklus 1 memperoleh persentase $65,51 \%$ meningkat pada siklus II menjadi 93,10\% dengan demikian hasil belajar siswa telah berhasil mencapai indikator keberhasilan yang telah ditentukan yaitu $\geq 70 \%$.

\section{DAFTAR PUSTAKA}

Apriliansyah, Rizki. 2015. Pengaruh Model Pembelajaran Student Facilitator and Explaining Terhadap Hasil Belajar Siswa Sekolah Dasar. JPGSD. 1 (2).

Ardianti, S.D., (2015). Pengaruh Modul Tematik Inquiry-Discovery Terhadap Hasil Belajar Siswa Materi Metabolisme Pembentuk Bioenergi. Jurnal Refleksi Edukatika, 5(2).

Ardianti, S.D., Wanabuliandari S., \& Rahardjo S. (2019). The Implementation of E-JAS Science Edutainment To Improve Elementary School Student's Conceptual Understanting. Unnes Science Education Journal, 8(1): 1-6

Arikunto, Suharsimi. 2010. Prosedur Penelitian Suatu Pendekatan Praktek. Jakarta: Rineka Cipta.

Astuti, Luh Puspita dan Wiyasa, Komang Ngurah. 2020. Model Student Facilitator and Explaining Berbantuan Media Pop Up Meningkatkan Keterampilan Berbicara Bahasa Indonesia Siswa. Mimbar Ilmu. 25, (3).

Azizah, A. N., \& Fitrianawati, M. (2020). Pengembangan Media Ludo Math Pada Materi Pecahan Sederhana Bagi Peserta Didik Kelas III Sekolah Dasar. WASIS: Jurnal Ilmiah Pendidikan, 1(1), 28-35.

Elydawati. 2019. Model Pembelajaran Student Facilitator and Explaining untuk Meningkatkan Hasil Belajar Siswa Kelas V Sekolah Dasar. Seminar Nasional Pendidikan Dasar Uniiversitas Negeri Medan. 7-17.

Fitriani, Dhita et al. 2019. Peningkatan Hasil Belajar Siswa Muatan IPS Melalui Model Student Facilitator and Explaining pada Kelas IV A SDN Ngaglik 01. Jurnal Basicedu. 3 (1).

Hanafy, Muh Sain. 2014. Konsep Belajar dan Pembelajaran. Lentera Pendidikan. 17 (1): 66-79.

Kurniadewi, Nike. 2019. Penggunaan Roda Putar Puzzle Pintar Untuk Meningkatkan Hasil Belajar Mata Pelajaran IPS Siswa SD. Jurnal Teknodik. 23 (1), 79-89.

Maesaroh, Siti. 2013. Peranan Metode Pembelajaran Terhadap Minat Prestasi Belajar Pendidikan Agama Islam. Jurnal Pendidikan. 1 (1).

Nurkholis. 2013. Pendidikan Dalam Upaya Memajukan Teknologi. Jurnal Kependidikan. 1 (1).

Pangasean, Renaldy. 2016. Penerapan Model Pembelajaran Kooperatif Tipe Student Facilitator And Explaining Untuk Meningkatkan Sikap Nasionalisme Dan Hasil Belajar Siswa Pada Mata Pelajaran Ips Kelas Va Sd Negeri 2 Kesumadadi Lampung Tengah. Lampung: Universitas Lampung.

Rohman, Mohammad Zainur. 2017. Pengaruh Penerapan Model Pemelajaran Student Facilitator And Explaining (SFAE) Terhadap Hasil Belajar Siswa Kelas X Teknik Pemesinan Pada Mata Pelajaran Teknonologi Mekanik Di Smk Dharma Siswa 1 Sidoarjo. JPTM. 6 (1), 156-162.

Sentosa, Satria Suja. 2015. Penerapan Student Facilitator And Explaining Dengan Multimedia Dalam Meningkatkan Hasil Belajar Siswa Kelas IV SDN 2 Waluyorejo 2014/2015. Kalam Cendekia. 3 (5), 507-511.

Shoimin, Aris. 2014. Model Pembelajaran Inovatif. Yogyakarta: Ar-Ruzz Media.

Sujuni, Alfin et al. 2014. Meningkatkan Hasil Belajar Siswa melalui model Pembelajaran Kooperatif Tipe Studnt Facilitator And Explainig (SFE). Berkala Ilmiah Pendidikan Fisika. 2 (1). 
Munia Ningsih, Sumarwiyah, dan Deka Setiawan

PENINGKATAN HASIL BELAJAR SISWA SEKOLAH DASAR MELALUI MODEL STUDENT ....

WASIS: Jurnal Ilmiah Pendidikan. Volume 1 Nomor 2, November 2020, hlm. 74-79

Sundari, Hanna. 2015. Model-Model

Pembelajaran dan Pemerolehan Bahasa

Kedua/Asing. Jurnal Pujangga. 1 (2).

Suprihatin, Siti. 2015. Upaya Guru dalam Menigkatkan Motivasi Belajar Siswa. Jurnal Pendidikan Ekonomi UM Metro. 3 (1), 73-82.

Supriyono. 2018. Pentingnya Media Pembelajaran untuk Meningkatkan Minat Belajar Siswa SD. Jurnal Pendidikan Dasar. 2 (1). 2614-4417.

Trianto, 2014. Model Pembelajaran Terpadu. Jakarta: Bumi Aksar.

Uno, Hamzah. 2015. Model Pembelajaran. Jakarta: PT Bumi Aksara.

Utari, Unga et al. 2016. Pembelajaran Tematik Berbasis Kearifan Lokal Di Sekolah Dasar Dalam Menghadapi Masyarakat Ekonomi Asean (MEA). Jurnal Teori dan Praksis Pembelajaran IPS. 1 (1).

Wahyuni, Dwi. 2017. Pengaruh Penggunaan Media Permainan Roda Keberuntungan Terhadap Kemampuan Menulis Hanzi pada Siswa Kelas XI Bahasa SMA Negeri Cerme Tahun Ajaran 2016/2017. 